\title{
BUILDING A COMMUNITY GARDEN: A COLLABORATIVE CROSS-DISCIPLINARY ACADEMIC COMMUNITY ENGAGEMENT PROJECT
}

\author{
Jeffrey R. Wozniak \\ Sam Houston State University • Huntsville, TX \\ Jeremy Bellah \\ West Texas A\&M University • Canyon, TX \\ Jason M. Riley \\ Sam Houston State University • Huntsville, TX
}

\section{ABSTRACT}

Most research concerning service learning discusses the benefits students experience when working on a project; however, for faculty, the challenges involved in facilitating the project are also great. We designed a collaborative crossdisciplinary project to address two goals: 1) to increase student engagement through service learning, while also 2) redistributing the work involved in managing the project from the instructor to a second group of upper-level operations management students. Specifically, we used the Academic Community Engagement (ACE) pedagogy, which combines community engagement with academic instruction, in a collaborative project between a freshman-level environmental science class and an upper-level operations management class. The project goal for the students was to research and establish a formal plan for the creation of a community garden in the local town. The community garden project goal was achieved over the course of the semester and survey results suggest that we accomplished both of the crossdisciplinary project goals. Specifically, many of the students developed a deeper sense of connection to the local community and a more tangible idea of how they can serve their communities in the future.

Keywords: Academic Community Engagement (ACE), community garden, environmental science, experiential learning, operations management, service learning

\section{INTRODUCTION}

Service learning projects can provide a more holistic educational experience at the undergraduate level. While the benefits of small scale, single semester service learning projects are considerable, larger scale (e.g., multiple classes and more than 
one community partners), and long-term (e.g., extending multi-semester) projects may offer students a more dynamic service learning experience. These large scale projects may also be beneficial to the community partners engaged in the project. However, while positive outcomes increase with project scope and scale, so do the project management and logistics challenges for instructors overseeing such projects. In response, we propose a collaborative, cross-disciplinary service-learning project that includes students from a target discipline (environmental science) and a support discipline (operations management) to assist in managing the project. For students, the learning objectives are enhanced by the cross-disciplinary design of the project. Specifically, students are exposed to several theoretical streams of research, including experiential learning, problem-based learning, and service learning. The target discipline students operated as content specialists and focused on the individual goals of the environmental science course. These students were responsible for the scientific research and design of the community garden project from an environmental science perspective. Conversely, the support discipline students functioned as project managers and applied operations management principles from their class to the project and target students. The support discipline students supervised all logistical, project, and operational processes associated with the community garden project.

The objective of this paper is to communicate the results of the implementation of a collaborative cross-disciplinary project to address two goals: 1) to increase student engagement through service learning, while also 2) redistributing the work involved in managing the project from the instructor to a second group of upper-level operations management students. In the following sections, we review the related literature, draw connections between different pedagogical foundations and this service learning project, describe the pedagogy in detail, and report both quantitative and qualitative data collected from project participants.

\section{LITERATURE REVIEW}

Service learning projects can take many forms, and at times borrow from different pedagogical foundations. Our cross-disciplinary project involves aspects of experiential learning, problem-based learning, and service learning. Here we highlight the use and application of these different subject areas in different academic settings and draw connections to their respective roles in this collaborative crossdisciplinary community garden project. 


\section{Cross-Disciplinary Projects}

Cross-disciplinary projects have been used in classes with great success at many universities, but often include disciplines that are closely related. Bhavnani and Aldridge (2000) for instance, described how product design projects were used to integrate different engineering disciplines at Auburn University. Similar projects were used at the University of Michigan and Stanford University, with the main difference being the inclusion of MBA students (Lovejoy and Srinivasan, 2001). Another project at Stanford University had architecture, engineering, and construction students' design, plan, and schedule construction projects on the university campus (Fruchter, 2001). Other university based cross-disciplinary projects include the use of semiconductor processing to integrate physics, chemistry, and engineering activities at San Jose State University (Muscat et al., 1998); the use of robotics to integrate engineering and computer science students at Southern Illinois University, Edwardsville (Weinberg, Engel, Gu, and Karacal, 2001); the use of a Proteomics Stock Market Project to integrate marketing, management, and biochemistry classes at Murray State University (Keller and Cox, 2004); and the use of a collaborative clinical teaching project used with nursing and clinical pharmacy across the College of Pharmacy and Health Sciences at Butler University, and the Indiana University School of Nursing (Robertson and McDaniel, 1995). Furthermore, some crossdisciplinary projects extend beyond on the academic institution itself. For example, Long and Carlo (2013) described a multi-institutional initiative involving students from supply chain management, production planning, scheduling, facility layout, and design courses. The goal was the design of a decentralized manufacturing organization for a company that planned to manufacture industrial Proton-Exchange Membrane fuel cells. While all of these projects were successful at integrating multiple, closely related disciplines, they stopped short of actually implementing the deliverables and expanding the collaborative scope to far reaching disciplines.

\section{Experiential Learning}

Existing research suggests that experiential learning is used by educators to help students understand concepts taught in class (Ferrari and Chapman, 2014). Based on Kolb's (1984) learning cycle, this pedagogy involves learning activities such as concrete experience (direct observation), reflective observation (evaluation, comparison), abstract conceptualization (modeling and analysis), and active experimentation (synthesis, design), which leads to a new concrete experience. Examples of service learning include the development and publication of quality 
management content (Foster, Jr., 2004), the use of simulation to demonstrate the complexity of project management execution (Hartman, et al., 2013), turning business cases into consulting exercises (Erzurumlu and Rollag, 2013), and hands-on research to stimulate learning in an introductory management information systems course (Wu and Sankar, 2013). In our community garden project, students from the target and support disciplines gained different forms of experiential learning exposure. The environmental science students for example, engaged in active experimentation when designing the community garden plan, while the support students partook in concrete experiences by directly interacting with target students. Further, all of students were required to write a reflective observation at the end of the project. This allowed the participants to reflect on their overall experience.

\section{Problem-Based Learning}

Problem-based learning (PBL) uses the problem-solving context to facilitate experiential learning. When using this pedagogy, students are presented with a problem, and then use the appropriate theory and tools to solve the problem. Many researchers support the need for PBL in higher education (Lenschow, 1998; Rouvrais et al, 2006; Lehmann, et al., 2008). According to Lenschow (1998), the choice of projects is extremely important to the pedagogy because the degree to which the project actually reflects reality determines its effectiveness. When students work on projects that accurately reflect reality, they learn from their experiences. Thus, PBL offers significant benefits when compared with traditional lecturing (Hicks, 1996). A benefit of working on projects that reflect reality is that the likely cross disciplinary lines. This is important because university students need to understand how organizations from varying backgrounds function (Athavale et al., 2008).

PBL has been implemented at many universities. Heineke, et al. (2010), for instance, described an interactive exercise used to teach the concepts of uncertainty and variability. An innovative teaching method introduced by Nargundkar, et al. (2014) presented problems first, with blank spaces for students to work them out. After the problems were presented, key concepts and the corresponding theory were provided. These tools enabled students to understand and ultimately solve the problem. The authors presented evidence suggesting that the proposed method improved critical thinking skills.

With our community garden project, we employed PBL by presenting the "problem" of food security in the city of Huntsville, Texas. Huntsville is a mostly rural community with a population of 40,435 and a median household income from 
2012-2014 of $\$ 29,257$ (US Census Bureau, 2016). With 37.3\% of the population living below the poverty level (US Census Bureau, 2016), we assert that food security is a concern for public officials and the community at large. Students were presented with this issue as a real world problem and were tasked with the need for a real-time, community-based solution. Addressing food security was fundamental to the project and served as a driving force for both target and support students throughout the duration of the project.

\section{Service Learning}

"Service learning refers to a teaching strategy that engages students in organized service activities" (What, 2015). Instructors regularly leverage this learning technique when teaching students how to work with community organizations and clients. These types of undertakings are called service-learning projects because they provide real value to the receiving organizations. While generally effective, class based projects are often difficult to implement since they are time-consuming and require much coordination when they involve interacting with individuals or organizations outside of the university. The current research is additionally complex since our project crossed disciplines (environmental science and operations management) and was planned to elapse over multiple semesters.

Service learning projects have been used extensively within the university setting. For instance, students in a strategic management capstone course, at Indiana State University, acted as consultants and offered advice to local businesses with respect to organizational objectives (Robinson, et al., 2010). Similarly, Xavier University students worked with local non-profit organizations while completing a project management course (Kloppenborg and Baucus, 2004). Larson and Drexler (2010) designed a service-learning assignment for a project management course where students planned and executed events for local charitable organizations. Business and communication students at California State University, Fullerton, participated in a community project to advise Target (department store) about how to communicate with college students to find future leaders (Brzovic and Matz, 2009). Students at Grand Valley State University worked to solve problems at the university in a course focused on teaching students how to function effectively as members of a work team (McKendall, 2000). Students at the University of Nebraska, Kearney learned six sigma concepts in the context of collaborating with local businesses on quality improvement projects (Zuckweiler, 2011). Students at Kansas State University participated in Total Quality Management (TQM) projects for local businesses, 
integrating the disciplines of engineering, business, statistics, and human ecology (McCahon and Lavelle, 1998). Faculty members at Western Carolina University used service learning projects to collaborate across multiple classes and multiple semesters for a management information system course (Richmond, et al., 2008). Sroufe and Ramos (2011) compiled information from experiences with 39 service learning projects over a 3-year period and suggested a pedagogy for delivering live projects in MBA curriculum focusing on sustainability concepts. These projects provided tremendous value to the participating organization and enabled the students involved a unique learning opportunity.

For typical service learning projects, the instructor initiates the project, assigns students to an appropriate team, and provides supervision throughout (Heriot, et al., 2008). This requires a number of critical resources including the instructor's time (Cook and Belliveau, 2005). Heriot and Campbell (2002) also found that it can be difficult to recruit and supervise project participants. Further, some of these resource requirements may be reduced by modifying the project structure or by shifting the workload to students (Heriot et al., 2008). However, we caution that this could result in poorer results for the client and a less than ideal educational experience for the student.

To potentially lessen the instructor's time, our project sought to place the operations management students in a leadership role where they directed the project and managed interactions with community partners. Giving both support to the instructor and real work exposure to the operations management students.

\section{METHODOLOGY}

\section{Pedagogy}

Our suggested pedagogy builds upon the model proposed by Bellah (2014). In this model, students in an applied project management course are used to manage a project in a target discipline. The management students act as "student facilitators" working to increase student communication and productivity throughout the project. There are multiple benefits to this pedagogy. First, the instructor of the target discipline course in which the project is conducted changes roles. Instead of acting as the project manager, he/she becomes a project stakeholder. This reduced role allows the instructor to focus on course objectives rather than spending significant time managing the project. In addition to reducing the instructor's workload, the pedagogy should result in improved project outcomes, a more diversified educational 
experience for students in the management course, as well as improved collaborative skills for students in the target course (Bellah, 2014).

Leveraging Bellah's (2014) model, we propose using students in a decision science course (project management, operations management, etc.) to initiate, plan, execute, monitor, control, and close all of the processes involved in service learning projects. We believe that this would provide multiple direct and indirect benefits. In addition to providing service learning opportunities for the decision science students, it exposes them to diverse ideas and concepts in a different discipline. Additionally, it benefits the instructor and students in the target discipline course, as it should result in a smaller workload for the instructor, better coordination, communication and control of projects, and improved learning outcomes for all students involved.

\section{Application Of The Pedagogy: Cross-Disciplinary Collaborative Project}

We designed a collaborative project to address two goals: 1) to increase student engagement through service learning, and 2) to redistribute some of the work involved in managing the project from the instructor to students. The project was implemented using an operations management class with 40 students (support discipline), and an environmental science class with 90 students (target discipline). The operations management students managed the project that was executed by the environmental science students. The project's goal was to research, design, and establish a formal procedure for the creation and operation of a local community garden.

The project was planned as part of an Academic Community Engagement (ACE) courses. The ACE pedagogy enables student learning by developing collaborative partnerships between the university and local community members. When using the ACE methodology, a faculty member works in collaboration with a community partner to design an engagement experience that is directly linked to course objectives and meets a community need. The ACE project is structured to occur in addition to the specific lecture components of the course, but works to directly leverage the over-arching themes found within the course. A structured written reflection on the community engagement experience is required and is assessed as a part of the final course grade. Unlike service learning experiences, ACE projects are structured to go beyond community service and attempt to link a student's academic learning to community needs.

Students in the target environmental science class were given the opportunity 
to choose from one of twenty different groups which they remained in for the entire semester long project (Table 1). We found that letting students choose their group, rather than placing student in pre-determined groups, worked to more effectively match student interests with individual group goals and in the end lead to improved quality of student products. Operations management students were divided into 10 groups corresponding to the 10 knowledge areas defined by the PMBOK Guide (Project Management Institute, 2013). Each group was responsible for managing the environmental science groups' work with respect to one knowledge area. The Project Integration group was responsible for integrating information from different groups to compile a single consistent deliverable. The Project Scope Management group was responsible for helping environmental science groups to define the scope of their work and verifying that they actually accomplished their goals. The Project Time Management group was responsible for helping the environmental science groups to define activities required to complete the project work, estimate the time involved in those activities, and keep track of the actual time worked. The Project Cost Management group was responsible for estimating and keeping track of all cost related items involved in the project. The Project Quality Management group was responsible for helping the environmental science students to define success criteria for each group and evaluating them with respect to the criteria. The Project Human Resource Management group was responsible for keeping track of the group members for all groups in both classes. The Project Communications Management group was responsible for defining how communication would happen throughout the project. The Project Risk Management group was responsible for documenting all possible risks and planned responses. The Project Procurement Management group was responsible for finding procurement sources for all necessary materials for the project. Finally, the Project Stakeholder Management group was responsible for identifying and communicating with stakeholders.

To facilitate communication between the target and support discipline classes, students were required to attend three joint class sessions. During these joint meetings, the faculty members provided status updates and groups were able to both trouble shoot project issues, as well as request critical information from other groups. Management students were able to utilize these sessions to provide face-toface guidance and directives to target discipline students. In addition, to facilitate information sharing between groups, a Wikispaces page (www.wikispaces.com) was created, with each group having their own space on the website. This allowed students to post documents, comments and questions to other group's pages and served as the main document sharing portal for the entire project. At the end of the 
semester, all students again convened for a group session where each environmental science target group (Table 1) gave an oral presentation on their group's findings and linked their efforts to the goal of establishing a formal plan for the creation of a community garden in the local town. Community partners and stakeholders in the garden project were invited to attend this semester ending presentation.

\section{RESULTS AND DISCUSSION}

At the end of the semester, we performed both quantitative and qualitative analysis to determine the effectiveness of the pedagogy. For the operations management students, the instructor's goal was to provide students a better understanding of basic project management concepts and to expose them to diverse ideas and perspectives related to environmental science. For the environmental science students, the goal was to link the core concepts from class (e.g., agriculture, food security, and sustainability) to the community engagement experience and to increase their likelihood the students would actively participate in similar projects in the future.

\section{Quantitative Analysis}

The survey instrument was designed to compare differences between project-based and lecture-based classes and determine what students learned about operations management, project management, and environmental sciences (see Appendix 1). We adapted survey questions from existing business case research measures (Erzuruml and Rollag, 2013). To evaluate the responses, we used a 7-point Likert scale: strongly disagree $=1$, disagree $=2$, somewhat disagree $=3$, neither disagree nor agree $=4$, somewhat agree $=5$, agree $=6$, strongly agree $=7$. We also asked respondents to comment on the project with an open-ended question.

For the operations management students, we collected survey data from the 38 of the 40 students who participated in the service-learning project at the end of spring semester 2014 (Table 2). Upon detailed inspection, we note that 35 of 37 respondents were in their 4th year of college (1 respondent did not answer the class year question), confirming that participants were senior level management students. Since the management students were in a leadership position during the project, their senior level, as compared to the freshman-level environmental science students, was preferred.

To determine the effectiveness of the project-leaning approach, we analyzed the survey results to understand the students' preferences (Table 3). In the results 
profile, we categorized responses into two groups: Disagree 1-3 (strongly disagree, disagree, or somewhat disagree) and Agree 5-7 (somewhat agree, agree, or strongly agree). We then reported the percentage of responses for each group.

Unlike Erzurumlu and Rollag (2013), the management students in this class did not prefer the project approach to the traditional in-class lecture format. In fact, only $39 \%$ of management students indicated they enjoyed the overall experience. The survey results further indicated the majority of students did not feel the project helped them identify (53\% disagreed), think through (58\% disagreed), or motivate them (53\% disagreed) better than an in-class discussion would. Particularly concerning was the fact that only $24 \%$ of respondents agreed the project approach enabled them to think through different issues.

While the evidence suggests the project approach, as compared to traditional in-class discussions, was less appealing for management students, our analysis also indicated that these management students believed they were able to better identify and understand operational issues. Since this was an operations management class, we appreciated the fact that students believed the project-management approach allowed them to identify operational issues $79 \%$ of the time and understand potential and actual operations issues $71 \%$ of the time. Further, since the management students actively participated in the initial stages of this project, we surmise they were able to identify and understand operations issues associated with the project planning and execution stages.

Our analysis further indicated that the management students felt the project approach helped them understand real-world business issues $71 \%$ of the time. Because the majority of respondents were 4 th year students, we assume they will be graduating and entering the business world shortly. Thus, by exposing them to real world issues like project planning, deliverable execution, and teamwork, the project approach seems to prepare these students for the job market. It does so by providing details about experiences. We expect that students can leverage the experiential details when discussing real world situations with potential employers.

Lastly, the analysis indicated $82 \%$ of management respondents felt they were involved with the community garden project. We believe this was a good indicator for class participation. Hence, the project approach may provide a method to keep students engaged. This is particularly important as instructors work to engage and motivate students who are nearing graduation.

Besides the survey questions, we also asked the management students several open-ended question about their overall experience. 
1) (The project) made me aware of subject matters outside of my academic major, better than in-class discussions.

2) (The project) made me aware how businesses and environmental groups could work together, better than in-class discussions.

3) The project got me excited by showing me how businesses and community groups work together.

Over $60 \%$ of the students agreed with each of these statements. Contrast that with the fact that only $24 \%$ of students agreed with the statement, "I would like to learn more about environmental science." The responses to the latter statement suggest that the students were not interested in the different discipline; therefore, the results of the former questions are much more powerful. Despite not having an overwhelming appreciation for environmental science, the management students recognized that the diverse topics were beneficial.

\section{Qualitative Analysis}

Environmental science students who participated in the project were required to write a reflective essay about their experiences with the project. These essays showed that students' experiences with the project varied. Numerous students noted that they did not enjoy working on the project. Many specifically noted the challenges associated with group work as the reason for this displeasure. The written reflections further illustrated that some of the environmental science students did not form a close connection with their management student counterparts. However, we did find that the community garden project was seen as a positive experience for the environmental science students. Many of the respondents wrote about a connection between the environmental science lecture material and its direct application to the community garden project. Specifically, many students reported they developed a deeper sense of connection to the local community and a more tangible idea of how they can serve the community.

\section{Conclusion}

The management students were vital in managing the project as they aided the target discipline students in creation of group timelines, task execution, and project 
documentation. Throughout the process, many environmental science students had difficulty understanding the role of the management students and often were uncertain with level of authority the management students' held. We acknowledge that the different roles were not defined in a clear manner at the onset of the project and attribute this confusion to this fact. Future iterations of this pedagogy would benefit from a more detailed presentation of the roles of the management students and the target discipline students, and the interaction between the groups, at the start of the project. In the future, the goal will be to illustrate to all students that they are all working in collaboration on the project and the increased communication between management and target discipline students will only result in a more developed final product.

We were unable to follow Bellah's (2014) model completely because the management students had not previously completed a project management course. Instead, the management students had been exposed to project management principles for two weeks during an operations management class. In retrospect, this limitation in resources likely affected the accomplishment of project goals.

This study provided key insight in to the how experiential learning, problembased learning, and service learning can be used to enhance teaching and student experiences. Because this was the first time attempting such an endeavor, we encountered multiple unforeseen challenges. Some students displayed negative comments related to the experience, but we believe much of the reason behind these comments were due to the exploratory nature of the project and were necessary "growing pains", which occurred throughout the semester. Moving forward, we plan to refine our processes and experiment in many different courses related to decision sciences. In addition, we plan to operationalize many of our processes so they can be replicated for other instructors who want to connect their students with diverse disciplines and the community outside the university.

It is important to expose students to diverse ideas and perspectives in education. This can be accomplished successfully by using service learning projects. While the benefits of these projects are great, they come at a cost. The management of the projects always requires significant time and resources, and this can be overwhelming as class size or the number of classes grow. Our proposed pedagogy attempts to achieve the benefits of service learning while managing the logistical challenges. Our results also show that tangible benefits occurred from the project to students and faculty in both disciplines. 


\section{ACKNOWLEDGMENTS}

The authors would like to acknowledge The Center for Community Engagement (CCE) at Sam Houston State University and extend appreciation to Dr. Joyce McCauley and Dr. Lee Miller. In addition, we thank the CCE Advisory Board and the Academic Community Engagement College Coordinators - without their support of Academic Community Engagement this work would not have been possible.

\section{FUNDING}

This research received no specific grant from any funding agency in the public, commercial, or not-for-profit sectors.

\section{REFERENCES}

Athavale, M., Davis, R. and Myring, M. (2008). The integrated business curriculum: An examination of perceptions and practices. Journal of Education for Business, 291-301.

Bellah, J. (2014). A Systems Perspective of Project Management to Support Service Learning Projects. The Proceedings of SWDSI.

Bhavnani, H.S. and Aldridge, M.M. (2000). Teamwork across disciplinary borders:

A bridge between college and the work place. Journal of Engineering Education, 13-16.

Brzovic, K. (2009). Students advise fortune 500 company: Designing a problembased learning community. Business Communication Quarterly, 72(1): 21-34.

Cook, R.G. and Belliveau, P. (2005). The experiential student team consulting process. Dog Ear Publishing.

Erzurumlu, S.S. and Rollag, K. (2013). Increasing Student Interest and Engagement with Business Cases by Turning Them into Consulting Exercises. Decision Sciences Journal of Innovative Education, 11(4): 359-381.

Ferrari, J.R. and Chapman, J.G. (2014). Educating students to make a difference:

Community-based service learning. Routledge.

Foster, S.T. (2004). FreeQuality: Using Service Learning to Motivate Student Learning. Decision Sciences Journal of Innovative Education, 2(1): 57-63.

Fruchter, R. (2001). Dimensions of Teamwork Education. Journal of Engineering Education, 17(4-5): 426-430. 
Fruchter, R. and Emery, K. (1999). Teamwork: Assessing cross-disciplinary learning. Proceedings of the 1999 conference on Computer support for collaborative learning. International Society of the Learning Sciences.

Govekar, M.A. and Rishi, M. (2007). Service learning: Bring real-world education into the B-school classroom. Journal of Education for Business, 3-10.

Hartman, N.S., Watts, C.A. and Treleven, M.D. (2013). Appreciating the Complexity of Project Management Execution: Using Simulation in the Classroom. Decision Sciences Journal of Innovative Education, 11(4): 323-334.

Heineke, J., Meile. L., Liu, L.B., et al. (2010). Project flip: a project management case/exercise experience. Decision Sciences Journal of Innovative Education, 8(1): 113-127.

Heriot, K.C. and Campbell, N.D. (2002). Starting new small business institute programs: A survey of new programs begun since 1996. Journal of Small Business Strategy, 13(2): 90-96.

Heriot, K.C., Cook, R., Jones, R.C., et al. (2008). The use of student consulting projects as an active learning pedagogy: A case study in a production/operations management course. Decision Sciences Journal of Innovative Education, 6(2): 463-481.

Hicks, E.R. (1996). Experiential learning in a postgraduate project management programme. Education + Training, 38(3): 28-38.

Keller, H. and Cox, J.R. (2004). The proteomics stock market project - A crossdisciplinary collaboration in biochemistry and business education. Journal of Chemical Education, 81(4): 519-522.

Kloppenborg, T.J. and Baucus, M.S. (2004). Project management in local nonprofit organizations: Engaging students in problem-based learning. Journal of Management Education, 28(5): 610-629.

Kolb, D.A. (1984). Experimental Learning. Englewood Cliffs, NJ: Prentice-Hall.

Larson, E. and Drexler (Jr), J.A. (2010). Project management in real time: A servicelearning project. Journal of Management Education, 34(4): 551-573.

Lehmann, M., Christensen, P., Du, X., et al. (2008). Problem-oriented and projectbased learning (POPBL) as an innovative learning strategy for sustainable development in engineering education. European Journal of Engineering Education, 33(3): 283-295.

Lenschow, J.R. (1998). From teaching to learning: A paradigm shift in engineering education and lifelong learning. European Journal of Engineering Education, 23(2): 155-161. 
Long, S.K. and Carlo, H.J. (2013). Collaborative Teaching and Learning through Multi-Institutional Integrated Group Projects. Decision Sciences Journal of Innovative Education, 11(3): 233-241.

Lovejoy, S.W. and Srinivasan, V. (2001). Perspective: Ten years of experience teaching a multi-disciplinary product development course. The Journal of Product Innovation Management, 19: 32-45.

McCahon, C.S. and Lavelle, J.P. (1998). Implementation of cross-disciplinary teams of business and engineering students for quality improvement projects. Journal of Education for Business, 73(3): 150.

McKendall, M. (2000). Teaching groups to become teams. Journal of Education for Business, 277- 282.

Muscat, J.A., Allen, L.E., Green, D.H.E., et al. (1997). Interdisciplinary teaching and learning in a semiconductor processing course. Journal of Engineering Education, 653-658.

Nargundkar, S., Samaddar, S. and Mukhopadhyay, S. (2014). A Guided ProblemBased Learning (PBL) Approach: Impact on Critical Thinking. Decision Sciences Journal of Innovative Education, 12(2): 91-108.

Project Management Institute (2013). A Guide to the Project Management Body of Knowledge (PMBOK Guide), 5th Edition, Newtown Square, Pennsylvania: Project Management Institute, Inc.

Richmond, W., Banerjee, D. and White, B.J. (2008). Integrating curriculum across courses in the same semester and across semesters using a service learning project. Decision Sciences Journal of Innovative Education. 6(2): 509-513.

Robertson, K.E. and McDaniel, A.M. (1995). Interdisciplinary professional education: A collaborative clinical teaching project. American Journal of Pharmaceutical Education, 59: 131-136.

Robinson, D.F., Sherwood, A.L. and DePaolo, C.A. (2010). Service-Learning by doing - How a student-run consulting company finds relevance and purpose in a business strategy capstone course. Journal of Management Education, 34(1): 88-112.

Rouvrais, S., Ormrod, J., Landrac, G., et al. (2006). A mixed project-based learning framework: preparing and developing student competencies in a French Grande Ecole. European Journal of Engineering Education, 31(1): 83-93.

Sroufe, R. and Ramos, D. (2011). MBA program trends and best practices in teaching sustainability: Live project courses. Decision Sciences Journal of Innovative Education, 9(3): 349-369. 
United States Census Bureau (2016). Huntsville, Texas. Available at: http:// quickfacts.census.gov/qfd/states/48/4835528.html (accessed 25 March 2016). What is service learning? (2015, October). Retrieved from the Virginia Commonwealth University, Division of Community Engagement Web site: http://www.servicelearning.vcu.edu/what-is-service-learning/.

Weinberg, B.J., Engel, L.G., Gu, K., et al. (2001). A multidisciplinary model for using robotics in engineering education. American Society for Engineering Education.

Wu, Y. and Sankar, C.S. (2013). Impact of Hands-On Research Experience on Students' Learning in an Introductory Management Information System Course. Decision Sciences Journal of Innovative Education, 11(4): 335-358.

Zuckweiler, K.M. (2011). Teaching six sigma to undergrads: A simplified real project approach. Decision Sciences Journal of Innovative Education, 9(1): 137-142. 


\section{BIOGRAPHICAL SKETCH OF AUTHORS}

Jeffrey R. Wozniak is an Assistant Professor of Biological Sciences at Sam Houston State University. He received his $\mathrm{PhD}$ from Florida International University and his BS from Allegheny College. Dr. Wozniak is an ecosystem ecologist and his research interests include coastal, estuarine and wetlands ecology. He teaches a wide range of environmental science, ecology and sustainability courses and often includes Academic Community Engagement in these offerings.

Jeremy Bellah is an Assistant Professor of Computer Information Systems and Decision Management at West Texas A\&M University. He received his Ph.D. from Texas Tech University. Dr. Bellah teaches classes in software development and project management. He conducts research in the areas of offshore information systems development, RFID technology utilization, software use in small and medium sized enterprises, and pedagogical research related to project management. He has published in journals including Journal of Computer Information Systems, International Journal of Productivity and Quality Management, and Journal of Information Technology Case and Application Research.

Jason M. Riley earned his Ph.D. from Clemson University. He is an assistant professor of supply chain management in the department of management and marketing at Sam Houston State University. Dr. Riley's research interests include supply chain risk, retail product management, and course modality. He has published in several peer-reviewed journals including the International Journal of Information Systems and Social Change, Journal of Business Management, and International Journal of Physical Distribution and Logistics Management. 
Table 1

List of the main organizational themes and twenty student subgroups for the community garden project in the target environmental science course.

\section{Project Introduction, Purpose and Implementation Plan}

1. Implementation plan: overview and organization

2. Mission statement and needs assessment

3. Local community asset assessment

\section{Overview of Other Community Gardens}

4. Successful community garden summary

5. Garden reconnaissance and site visits

\section{Garden Site Selection, Preparation and Planning}

6. Local site selection: options and feasibility

7. Site preparation

8. Soil chemistry

\section{Garden Components and Operation}

9. Organic farming

10. Composting 101

11. Garden security and safety

12. Garden signage

\section{Outreach and Education}

13. K-12 educational opportunities

14. University educational opportunities

15. Garden communication network

16. Publicity and community outreach

\section{Long-term Garden Sustainability}

17. Garden rules and procedures

18. Garden budget

19. Garden financial sustainability plan

20. Garden master plan and organization 
Table 2

Descriptive Statistics

\begin{tabular}{|c|c|c|c|c|c|}
\hline $\begin{array}{l}\text { Compared to in-class } \\
\text { discussions, the project }\end{array}$ & Count & Mean & $\begin{array}{l}\text { Std } \\
\text { Dev }\end{array}$ & Min & Max \\
\hline $\begin{array}{l}\text { Helped me to identify different issues better than in-class } \\
\text { discussions. }\end{array}$ & 38 & 3.55 & 1.62 & 1 & 7 \\
\hline Helped me to think through different issues... & 38 & 3.37 & 1.62 & 1 & 7 \\
\hline Helped me to apply critical reasoning... & 38 & 3.68 & 1.58 & 1 & 7 \\
\hline Stimulated my interest in the course subject... & 38 & 3.50 & 1.69 & 1 & 6 \\
\hline Motivated me to do my best work... & 38 & 3.55 & 1.52 & 1 & 6 \\
\hline Allowed me to learn more about the subject matter... & 38 & 3.47 & 1.62 & 1 & 7 \\
\hline $\begin{array}{l}\text { Made me aware of subject matters outside of my } \\
\text { academic major... }\end{array}$ & 38 & 4.53 & 1.66 & 1 & 7 \\
\hline $\begin{array}{l}\text { Made me aware how businesses and environmental } \\
\text { groups could work together... }\end{array}$ & 38 & 4.64 & 1.69 & 1 & 7 \\
\hline \multicolumn{6}{|l|}{ General response to the project } \\
\hline The project allowed me to identify operational issues. & 38 & 5.16 & 1.39 & 1 & 7 \\
\hline The project allowed me to understand operational issues. & 38 & 4.92 & 1.51 & 1 & 7 \\
\hline The project helped me apply concepts I learned in class. & 38 & 4.55 & 1.43 & 1 & 7 \\
\hline I gained valuable experience from this project. & 38 & 3.97 & 1.67 & 1 & 7 \\
\hline I was involved with this project. & 38 & 5.42 & 1.46 & 1 & 7 \\
\hline Overall, the project was helpful to my learning. & 38 & 4.18 & 1.72 & 1 & 7 \\
\hline Overall, I enjoyed the experience. & 38 & 4.00 & 1.76 & 1 & 7 \\
\hline I would like to learn more about project management. & 38 & 5.50 & 1.16 & 2 & 7 \\
\hline I would like to learn more about environmental science. & 38 & 2.95 & 1.68 & 1 & 6 \\
\hline $\begin{array}{l}\text { The project got me excited by showing me how buinesses } \\
\text { and community groups work together. }\end{array}$ & 38 & 4.68 & 1.44 & 2 & 7 \\
\hline Allowed me to understand real world business issues. & 38 & 5.11 & 1.45 & 1 & 7 \\
\hline $\begin{array}{l}\text { The project challenged my thinking about } \\
\text { environmental science. }\end{array}$ & 38 & 3.47 & 1.66 & 1 & 7 \\
\hline $\begin{array}{l}\text { The project helped me realize there is more to the world } \\
\text { than just business. }\end{array}$ & 38 & 4.42 & 1.37 & 2 & 7 \\
\hline \multicolumn{6}{|l|}{ Control Questions } \\
\hline Gender & 36 & 1.47 & 0.56 & 1 & 2 \\
\hline First Generation Student & 36 & 1.47 & 0.51 & 1 & 2 \\
\hline Age & 35 & 22.54 & 2.02 & 19 & 30 \\
\hline Class Year & 37 & 3.95 & 0.23 & 3 & 4 \\
\hline
\end{tabular}


Table 3

Result Profile

\begin{tabular}{|c|c|c|c|c|c|c|}
\hline $\begin{array}{l}\text { Compared to in-class } \\
\text { discussions, the project }\end{array}$ & Count & Mean & $\begin{array}{c}\text { Disagree } \\
\text { 1-3 }\end{array}$ & $\begin{array}{c}\text { Disagree } \\
\%\end{array}$ & $\begin{array}{l}\text { Agree } \\
1-3\end{array}$ & $\begin{array}{c}\text { Agree } \\
\%\end{array}$ \\
\hline $\begin{array}{l}\text { Helped me to identify different issues better than in- } \\
\text { class discussions. }\end{array}$ & 38 & 3.55 & 20 & $53 \%$ & 15 & $39 \%$ \\
\hline Helped me to think through different issues... & 38 & 3.37 & 22 & $58 \%$ & 9 & $24 \%$ \\
\hline Helped me to apply critical reasoning... & 38 & 3.68 & 17 & $45 \%$ & 12 & $32 \%$ \\
\hline Stimulated my interest in the course subject... & 38 & 3.50 & 19 & $50 \%$ & 12 & $32 \%$ \\
\hline Motivated me to do my best work... & 38 & 3.55 & 20 & $53 \%$ & 13 & $34 \%$ \\
\hline Allowed me to learn more about the subject matter... & 38 & 3.47 & 18 & $47 \%$ & 10 & $26 \%$ \\
\hline $\begin{array}{l}\text { Made me aware of subject matters outside of my } \\
\text { academic major... }\end{array}$ & 38 & 4.53 & 11 & $29 \%$ & 24 & $63 \%$ \\
\hline $\begin{array}{l}\text { Made me aware how businesses and environmental } \\
\text { groups could work together... }\end{array}$ & 38 & 4.64 & 7 & $18 \%$ & 26 & $68 \%$ \\
\hline \multicolumn{7}{|l|}{ General response to the project } \\
\hline The project allowed me to identify operational issues. & 38 & 5.16 & 4 & $11 \%$ & 30 & $79 \%$ \\
\hline $\begin{array}{l}\text { The project allowed me to understand operational } \\
\text { issues. }\end{array}$ & 38 & 4.92 & 6 & $16 \%$ & 27 & $71 \%$ \\
\hline $\begin{array}{l}\text { The project helped me apply concepts I learned in } \\
\text { class. }\end{array}$ & 38 & 4.55 & 7 & $18 \%$ & 23 & $61 \%$ \\
\hline I gained valuable experience from this project. & 38 & 3.97 & 15 & $39 \%$ & 17 & $45 \%$ \\
\hline I was involved with this project. & 38 & 5.42 & 3 & $8 \%$ & 31 & $82 \%$ \\
\hline Overall, the project was helpful to my learning. & 38 & 4.18 & 11 & $29 \%$ & 17 & $45 \%$ \\
\hline Overall, I enjoyed the experience. & 38 & 4.00 & 15 & $39 \%$ & 15 & $39 \%$ \\
\hline I would like to learn more about project management. & 38 & 5.50 & 2 & $5 \%$ & 33 & $87 \%$ \\
\hline $\begin{array}{l}\text { I would like to learn more about environmental } \\
\text { science. }\end{array}$ & 38 & 2.95 & 24 & $63 \%$ & 9 & $24 \%$ \\
\hline $\begin{array}{l}\text { The project got me excited by showing me how } \\
\text { buinesses and community groups work together. }\end{array}$ & 38 & 4.68 & 9 & $24 \%$ & 23 & $61 \%$ \\
\hline Allowed me to understand real world business issues. & 38 & 5.11 & 5 & $13 \%$ & 27 & $71 \%$ \\
\hline $\begin{array}{l}\text { The project challenged my thinking about } \\
\text { environmental science. }\end{array}$ & 38 & 3.47 & 20 & $53 \%$ & 12 & $32 \%$ \\
\hline $\begin{array}{l}\text { The project helped me realize there is more to the } \\
\text { world than just business. }\end{array}$ & 38 & 4.42 & 8 & $21 \%$ & 17 & $45 \%$ \\
\hline
\end{tabular}




\section{Appendix 1 \\ Management Student Questionaire}

\section{Compared to in-class discussions, the project.}

1. Helped me to identify different issues better than in-class discussions.

2. Helped me to think through different issues better than in-class discussions.

3. Helped me to apply critical reasoning better than in-class discussions.

4. Stimulated my interest in the course subject better than in-class discussions.

5. Motivated me to do my best work better than in-class discussions.

6. Allowed me to learn more about the subject matter, than I would have during in-class discussions

7. Made me aware of subject matters outside of my academic major, better than in-class discussions

8. Made me aware how businesses and environmental groups could work together, better than in-class discussions

\section{General response to the project}

9. The project allowed me to identify operational issues

10. The project allowed me to understand operational issues

11. The project helped me apply concepts I learned in class.

12. I gained valuable experience from this project.

13. I was involved with this project

14. Overall, the project was helpful to my learning.

15. Overall, I enjoyed the experience.

16. I would like to learn more about project management

17. I would like to learn more about environmental science

18. The project got me excited by showing me how businesses and community groups work together.

19. Allowed me to understand real world business issues.

20. The project challenged my thinking about environmental science.

21. The project helped me realize there is more to the world than just business.

22. What did you like most about the project?

\section{Control questions}

23. Male/Female

24. Age:

25. Are you a first generation student (Neither parent graduated from a four year college or university): Yes, I am a first generation student, No, I am not a first generation student.

\section{Open-ended question}

26. What did you like about the project? 